\title{
SOC (STATE of CHARGE) THREE-CELLS LEAD DYNAMIC BATTERY MODEL
}

\author{
Kurriawan Budi Pranata ${ }^{1 *}$, Freygieon Ogiek Rizal Sukma², Muhammad Ghufron ${ }^{2}$, \\ Masruroh $^{2}$ \\ ${ }^{1}$ Department of Physiscs Education, University of PGRI Kanjuruhan Malang, Malang 65148, \\ Indonesia \\ ${ }^{2}$ Department of Physics, Faculty of Mathematics and Natural Science, University of Brawijaya, \\ Malang 65145, Indonesia
}

\begin{abstract}
The three-cells dynamic lead-acid battery has been widely manufactured as the latest secondary battery technology. It is being carried out by 10 cycles of charge-discharge treatment with various types of SoC, such as 100\% (Full charge $5100 \mathrm{mAh}$ ), 50\% (2550 mAh), 25\% (1275 mAh), and discharge current of $0.8 \mathrm{~A}$. This experiment aims to analyze the treatment of SOC conditions on the performance of the lead-acid battery. The cyclicality test has performed using a Battery Management System (BMS) by applying an electric current at charging $1 \mathrm{~A}$ and discharging $0.8 \mathrm{~A}$. The results of the SOC charging conditions at $100 \%, 50 \%, 25 \%$ respectively gave a difference in the value of voltage efficiency of $84 \%, 87 \%, 88 \%$, capacity efficiency values of $84 \%, 80 \%$, $69 \%$, energy efficiency values of $70 \%, 70 \%, 62 \%$. The $100 \%$ and $50 \%$ SOC treatments showed better performance and battery energy than the $25 \%$ SOC treatment. This research can be a recommendation to predict the performance of the lead-acid battery model during the charging and discharging process.
\end{abstract}

Keywords: Lead-acid battery; State of charge; Discharge current; Efficiency

\section{Introduction}

The demand for electrical energy in Indonesia is estimated growth by year. According to on the projection results of Perusahaan Listrik Negara (PLN), the number of customers consuming electricity from the household, business, public, the industrial sector in 2018 reached a total of 71,046 customers. The reference is also predicted by PLN in 2027 that the number of customers consuming electricity will continue to increase until it reaches 92,974 customers. ${ }^{1} \quad$ Therefore, new renewable energy must main concern of the Indonesian government. It is not an effort to reduce fossil energy but also to realize clean or environmentally energy. ${ }^{2}$ However, this energy has been faced the constraints of inconsistent energy fluctuations, which can impact the energy storage system. ${ }^{3}$

\footnotetext{
*Corresponding author.

E-Mail: kurriawan@unikama.ac.id
}

Dynamic Battery or Redox Flow Battery (RFB) is a promising energy storage technology it has a large storage capacity, relatively cheap, and reversible. ${ }^{4,5,6}$ In contrast, a dynamic battery is made to flow through the electrolyte tank outside the battery system using a low power pump. ${ }^{7,8}$ An electrochemical reaction occurs when the electrolyte flowing from the tank interacts. ${ }^{9}$ There are two types of dynamic batteries, ${ }^{10} \mathrm{a}$ single electrolytic dynamic batteries ${ }^{11,12}$ and dual electrolytic dynamic batteries. ${ }^{13}$ a single electrolyte dynamic battery is accommodated in a reservoir which is circulated to the battery cell unit such as a lead acid dynamic battery. ${ }^{14}$ Meanwhile, the double electrolyte uses two types of electrolytes which are accommodated in two different reservoirs. ${ }^{15}$ Usually, these electrolytes are called analyte and cataloyte. ${ }^{16}$ In this study, a single electrolyte lead-acid dynamic battery has a low economic value with reduced electrolyte 
costs and no ion separation membrane. ${ }^{17}$ In addition, this battery has a higher energy density and cell voltage. ${ }^{18}$ The lead-acid battery uses $\mathrm{H}_{2} \mathrm{SO}_{4}$ as an electrolyte with $\mathrm{Pb}$ (Anode) and $\mathrm{PbO}$ (Cathode) electrodes. The following is a description of the electrochemical reaction of lead-acid batteries during the Anode and Cathode processes $^{19}$ :

$$
\begin{array}{cc}
\mathrm{Pb}+\mathrm{SO}_{4}^{2-} \leftrightarrow \mathrm{PbSO}_{4}+2 e^{-} & 1 \\
\mathrm{~Pb}^{2+}+2 \mathrm{H}_{2} \leftrightarrow \mathrm{PbO}_{2}+4 H^{+}+2 e^{-} & 2
\end{array}
$$

During the charging process, lead (II) $\left(\mathrm{Pb}^{2+}\right)$ is reduced to lead $(\mathrm{Pb})$ at the negative electrode and oxidized to lead dioxide $\left(\mathrm{PbO}_{2}\right)$ at the positive electrode. On discharge (discharge), lead $(\mathrm{Pb})$ and lead dioxide $\left(\mathrm{PbO}_{2}\right)$ dissolve, forming lead (II) $\left(\mathrm{Pb}^{2+}\right)$, which again dissolves in electrolytes. ${ }^{15}$

RFB battery charging is too high. It (Overcharge) can be dangerous due to produces hydrogen gas. Hydrogen gas generated by electrolysis can cause fires and explosions. ${ }^{20}$ Battery management is needed to balance the battery cells and minimize damage. The important parameter is SoC, and $\mathrm{SoC}$ is defined as \% capacity in the battery. ${ }^{21}$ A $100 \%$ of SoC indicates the battery is fully charged. ${ }^{22}$

Ghufron et al. in 2017, reported that the time difference in different capacity values, it shown the highest capacity was obtained $3838 \mathrm{mAh}$ on 2.5 hours charging with the resulting voltage $2.12 \mathrm{~V}$ and requiring discharge time of 13779 s, while the lowest capacity was obtained $630 \mathrm{mAh}$ at 0 charging, 5 hours with a voltage of $2.17 \mathrm{~V}$ and required discharging time of 1988 second. ${ }^{23}$ it is known that \% SoC capacity has different effects and is expected to affect battery performance in the next cycle. ${ }^{22}$

In this study, the estimation of the state of charge is very important, and the battery does not experience a dangerous condition (works in a safe operating area) and minimizes a decrease in performance, evaluating the effect of SOC variation of $100 \%, 50 \%$ and $25 \%$ on dynamic lead-acid batteries and cycle repetitions.

\section{Methods}

Continuing research from Ramadhan, F. $\mathrm{R}$. et $\mathrm{al}^{24}$ Research using a three-cell leadacid dynamic battery. The electrodes used are GS Premium 6N6-3B-1 battery electrodes in the form of $\mathrm{Pb} 2+$ (Cathode) and $\mathrm{PbO}$ (Anode) connected in series, each electrode measuring $4.5 \times 7.5 \mathrm{~cm}^{2}$. The total electrolyte is $800 \mathrm{ml}$. The electrolyte is flowed to the electrode using a pump, as shown in Figure 1.

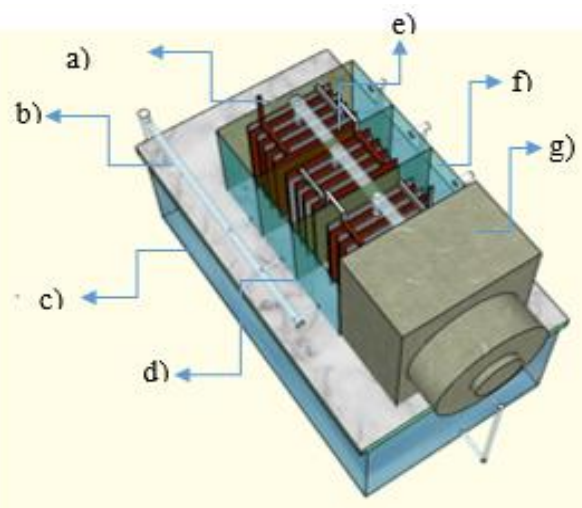

Figure 1. Design of three cell lead acid dynamic battery system, a) Electrolyte inlet, b) Electrolyte outlet, c) Electrolyte tank, d) Electrode tank, e) Electrode, f) Drain, g) Peristaltic Pump.

SoC value cannot be determined instantly. ${ }^{25}$ Therefore, an SoC value of $50 \%$ and $25 \%$ were obtained from the average percentage value of the full charge condition over many cycles. 10 cycles of data were collected using Turnigy Accucell-6 and Software ChargeMaster2.02. The data displayed is a graph of capacity, voltage, and current. This research was conducted by applying a constant charging current of $1 \mathrm{~A}$ and a constant discharge current of $0.8 \mathrm{~A}$. The selection of a lower current is expected not to damage the condition of the battery electrodes during the use of periodic chargedischarge scalability tests.

\section{Result and Discussion}

The battery is discharged firstly as a result of the spontaneous reaction that occurs between the sulfuric acid electrolyte and the two electrodes, as shown in Figure 2. 
Discharging the battery uses a constant current of $0.8 \mathrm{~A}$ for eight hours to determine the initial state of voltage (OCV) and battery capacity. The greater the open voltage value $(\mathrm{OCV})$, it can be seen that the energy stored or the battery capacity is also getting bigger.

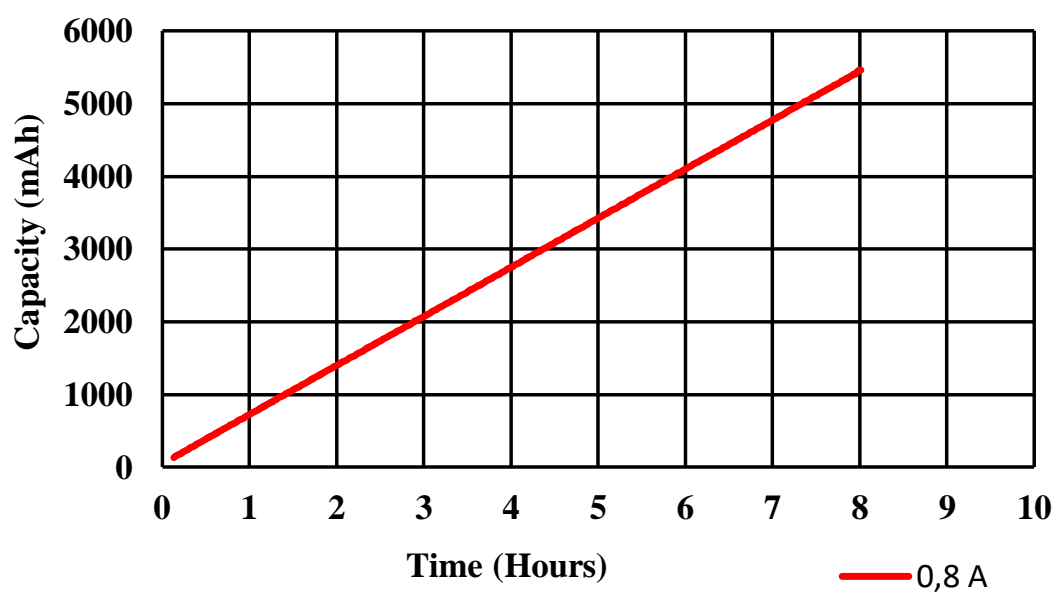

Figure 2. Initial discharge of 3 cells dynamic battery with a discharge current of $0.8 \mathrm{~A}$.

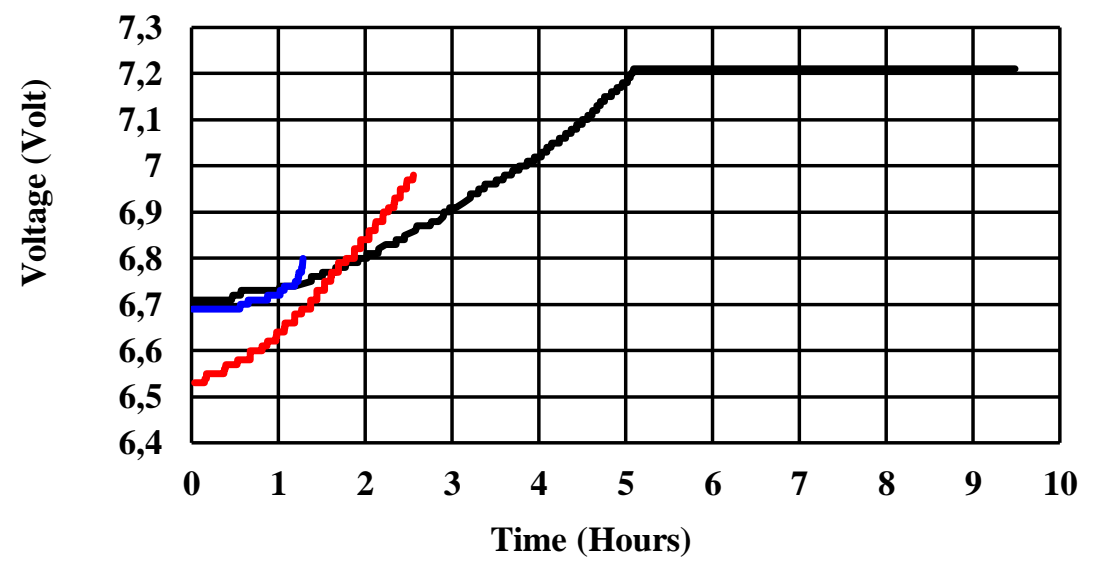

$-\operatorname{SOC} 100 \%-\operatorname{SOC} 50 \%-\operatorname{SOC} 25 \%$

Figure 3. Charging current $1 \mathrm{~A}$ on a 3 cell sweetened battery with SOC variations of $100 \%, 50 \%$, and $25 \%$

Figure 2, battery capacity has a linear graphical function with respect to time. It shows that battery capacity is the amount of charge stored over time. The result of this discharge has a final discharge capacity value of $5331 \mathrm{mAh}$. Figure 3, a 3-cell dynamic battery is charged 1A to the full the voltage reaches 7.21 Volts and Figure 4 discharges $0.8 \mathrm{~A}$ to the final voltage of 5.40 Volts. This filling-discharging treatment is performed for 10 cycles and is applied to $100 \%$ SoC conditions. Then $50 \%$ and $25 \%$ SoC variations were taken from the fully charged state (SoC 100\%). Then an experiment was performed to characterize the filling of the SoC $50 \%$ and SoC 25\%, as shown in Figure 3.

$100 \%$ SoC value is a fully charged condition (full charge). Furthermore, the SoC value of $50 \%$ and SoC $25 \%$ are the value of $50 \%$ of the full charge condition and $25 \%$ of the full charge condition. ${ }^{26}$ The average of 10 cycles with a discharge current of $0.8 \mathrm{~A}$ is $5100 \mathrm{mAh}$. Then the SOC $50 \%$ value is determined to be $2550 \mathrm{mAh}(50 \%$ of 5100 $\mathrm{mAh})$ and SOC $25 \%$ to be $1275 \mathrm{mAh}(25 \%$ of $5100 \mathrm{mAh})$. Meanwhile, the SOC 
variation of $50 \%$ and $25 \%$ used a discharge current of $0.8 \mathrm{~A}$.

Figure 3, at a constant charging current of $1 \mathrm{~A}$, the lead-acid dynamic battery has a cutoff voltage of $7.21 \mathrm{~V}$ when it reaches full charge. In the process of charging the SOC battery $50 \%$, the cutoff voltage is $6.98 \mathrm{~V}$ and SOC $25 \%$ the cutoff voltage is $6.86 \mathrm{~V}$. This affects the open-circuit voltage (OCV) value shown in Table 1.

Table 1. Operating voltage state of the SoC 100\%, 50\%, and $25 \%$

\begin{tabular}{ccccc}
\hline No & SOC & Vcutoff & OCV & Capacity \\
\hline 1 & $100 \%$ & 7,21 & 6,54 & $5100 \mathrm{mAh}$ \\
2 & $50 \%$ & 6,98 & 6,50 & $2550 \mathrm{mAh}$ \\
3 & $25 \%$ & 6,86 & 6,17 & $1275 \mathrm{mAh}$ \\
\hline
\end{tabular}

The open voltage (OCV) is the battery voltage when it is not given an external load. Table 1 shows that the greater the charging cutoff voltage has a value proportional to the open-circuit voltage. SOC $50 \%$ and $25 \%$ have an OCV value smaller than SOC $100 \%$. This is because when charging does not reach the full charged condition. The amount of charge stored in the battery has an impact on the OCV value. The greater the stored charge, the higher the battery's OCV value.

When charging $1 \mathrm{~A}$, a full charge takes longer than other SOCs, as shown in Figure 3. Figure 4 shows the large SOC of the battery, so the time required for discharge is longer. During the emptying process, the Vcutoff value of each is the same, namely $5.41 \mathrm{~V}$.

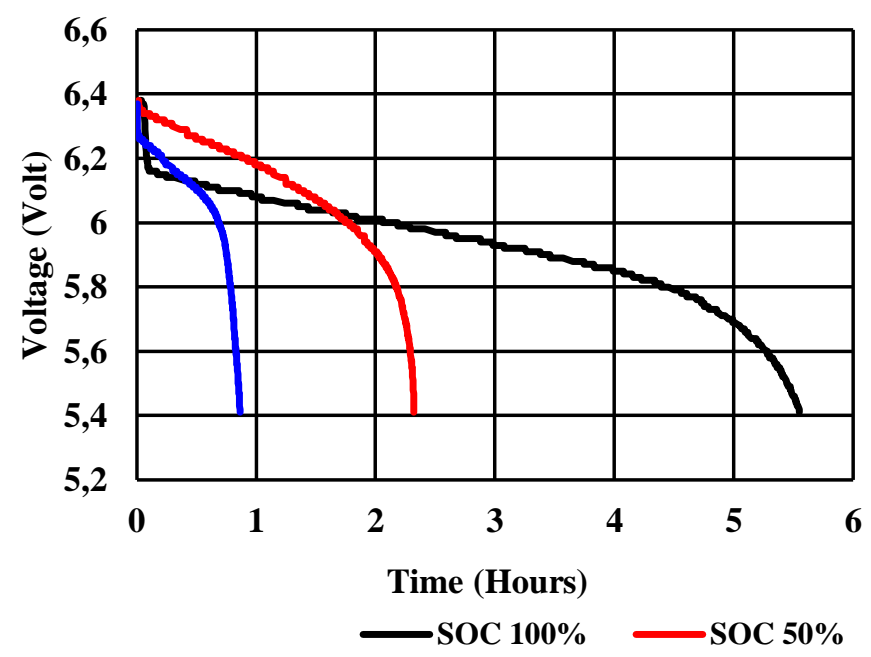

Figure 4. Voltage versus time curve for each SOC on discharge with a constant current of $0.8 \mathrm{~A}$

Figure 4 shows the length of time for the discharge of SOC of $100 \%, 50 \%$, and $25 \%$ for $5.6 \mathrm{~h}, 2.3 \mathrm{~h}$, and $0.9 \mathrm{~h}$, respectively. This different length indicates that the stored charge at the higher SOC condition is proportional to the amount of charge. The SOC value is proportional to the battery capacity. This statement is supported by the data in table 1 . SOC $100 \%, 50 \%$, and $25 \%$ each have a charge of $5100 \mathrm{mAh}, 2550 \mathrm{mAh}$, and $1275 \mathrm{mAh}$. As a physical equation representative, as shown in equation 5 .

$$
\begin{array}{ll}
i=\frac{d q}{d t} & 3 \\
\int_{0}^{t} d q=\int_{0}^{t} i d t & 4 \\
q_{t}=\int_{0}^{t} i d t & 5
\end{array}
$$

Figure 4 is in accordance with the physical statement in equation 5 . The greater the amount of battery charge is proportional to the length of discharging time. The SOC action treatment has a $100 \%$ effect on the amount of charge stored in a battery. 
It is shown in Figure 2 that the initial battery capacity is $5331 \mathrm{mAh}$. This value is not used for the full charge of a battery. A test to determine the full charge value of a battery, 10 charge-discharge cycles of a battery with a constant charge current of $1 \mathrm{~A}$ with a constant discharge current of 0.8 A the results shown in Figure 5.

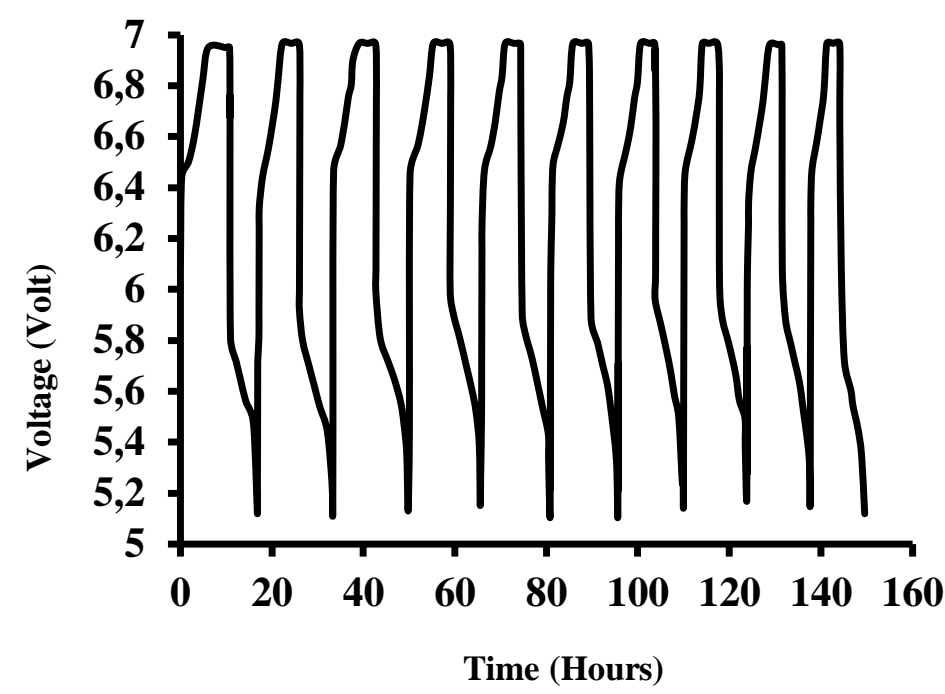

Figure 5. Ten cycles of 100\% SOC constant current charge $1 \mathrm{~A}$ and constant current discharge $0.8 \mathrm{~A}$.

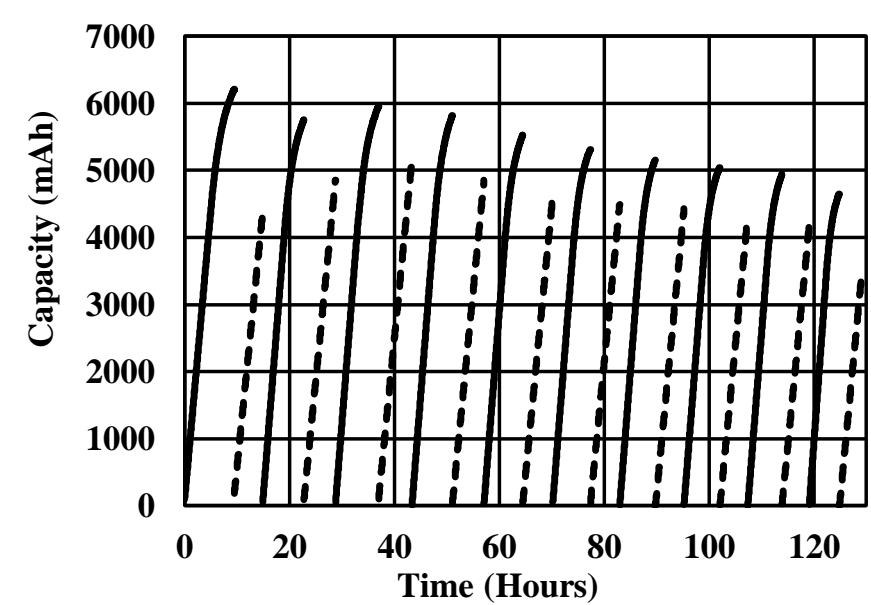

Figure 6. Ten cycles of $100 \%$ SOC capacity constant current charge 1 A and constant current discharge $0.8 \mathrm{~A}$.

Figure 5 shows 10 battery discharge cycles, and the time function takes a travel time of 149 hours. The 10 cycles form a curve that has an identical trend, but the width of the curve is narrower. In the 10th cycle, the area of the curve is getting narrower that identifies the decreasing energy density of the battery, which can be strengthened by the battery capacity value data from the 10 cycle test results as shown in Figure 6.
Figure 6 shows 10 charge-discharge cycles in the representation of battery capacity time function. It showed the value of the battery capacity in the 10th cycle has decreased. This reinforces that on the 10th cycle, the battery has decreased performance. The results of the $100 \%$ SOC discharge capacity of 10 cycles on an average of 5100 $\mathrm{mAh}$. These results are used as a basic reference that the capacity of the SOC condition is $100 \%$ full charge of $5100 \mathrm{mAh}$. It can be that the SOC $50 \%$ is determined to 
be $2550 \mathrm{mAh}(50 \%$ of $5100 \mathrm{mAh})$ and SOC $25 \%$ of $1275 \mathrm{mAh}(25 \%$ of $5100 \mathrm{mAh})$. To confirm this statement, a 10-cycle SOC 50\% test through the Turnigy Accu Cell device with a battery capacity setting point of 2550
mAh. This means that when charging has reached a capacity of 2550 mAh. Automatically stop the filling process. The test results for 10 cycles of $50 \%$ SOC are shown in Figure 7.

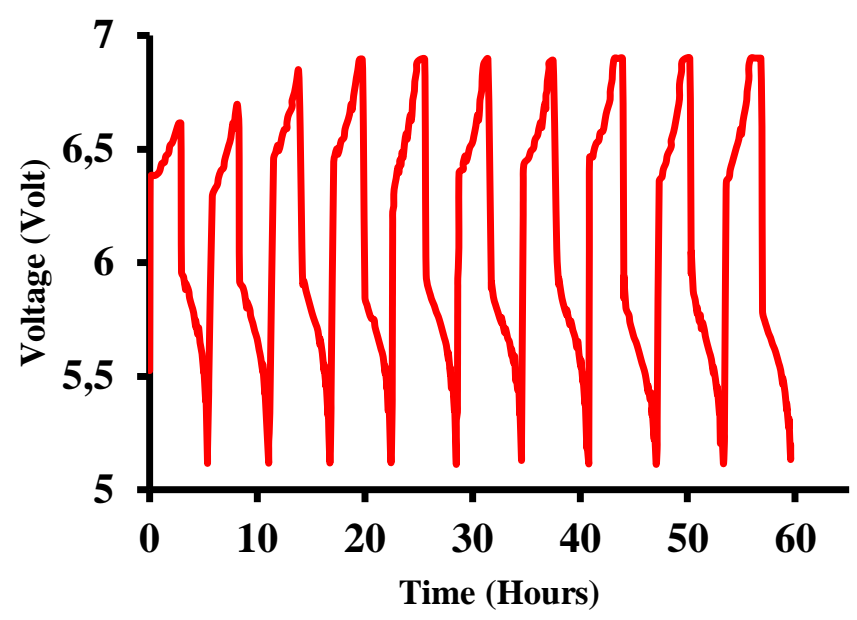

Figure 7. Ten cycles of 50\% SOC charge constant current $1 \mathrm{~A}$ and constant current discharge $0.8 \mathrm{~A}$.

Figure 7. The total time required for 10 cycles with $50 \%$ SOC charging is 52 hours. The average time per cycle was 5.2 hours. However, the SOC value of $50 \%$ is determined and constant each cycle. Charging time for subsequent cycles has increased. In the first cycle, the time required for $2550 \mathrm{mAh}$ charging is 2.5 hours, while the last time on the 10th cycle is 2.9 hours. The increase in the travel time of this cycle means that the value of the battery discharge capacity is getting bigger, as shown in Figure 8.

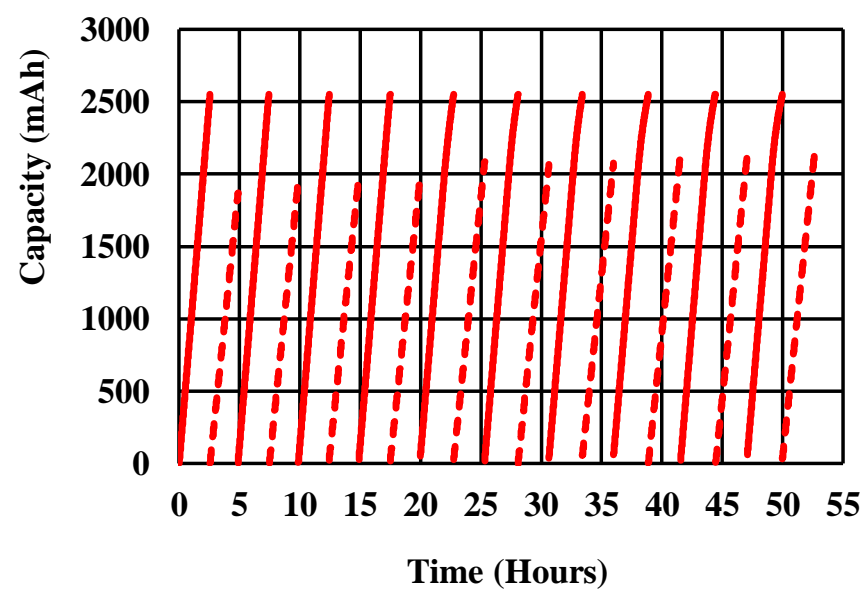

Figure 8. Ten cycles of 50\% SOC capacity constant current $1 \mathrm{~A}$ charge and 0.8 A constant current discharge.

Figure 8 . Shows the capacity of the 10 cycles of time function. The value of the battery capacity from the first cycle to the 10th cycle has increased over time. This indicates there is a charge remaining from the previous cycles. While the average discharge capacity from the measurement results is $2048 \mathrm{mAh}$ which is still relatively close to 
the SoC charging capacity value of $50 \%$ (2550 mAh). The three-cell dynamic battery that is made is proven to have good performance even though it is only given a charge of $50 \%$ of the full charge state.

To confirm the SOC is $25 \%$ of $1275 \mathrm{mAh}$ from the calculation of ( $25 \%$ of $5100 \mathrm{mAh})$.
A test of 10 cycles of constant current charging of $1 \mathrm{~A}$ and constant discharge of 0.8 $A$ in order to provide evidence of the statement of the calculation of the SOC value of $25 \%$ from $5100 \mathrm{mAh}$ of $1275 \mathrm{mAh}$. The test results are as shown in Figure 9.

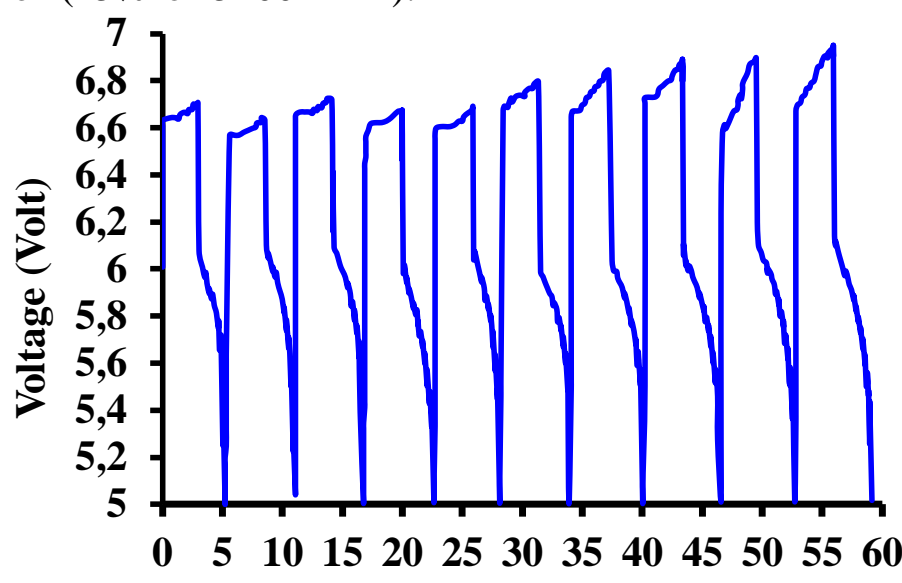

\section{Time (Hours)}

Figure 9. Ten cycles of $25 \%$ SOC constant current 1 A charge and $0.8 \mathrm{~A}$ constant current discharge.

The $25 \%$ SOC battery has a time of 10 cycles the fastest because the number of SOCs given is smallest than the others. The time of the SOC $25 \%$ or 1275 mAh battery is 23.6 hours with an average per cycle of 2.36 hours. In contrast to the $50 \%$ SOC battery. The time required for the charging process tends to be stable for the following cycles, which is 1.27 hours. Similarly to $50 \%$ SOC battery, the $25 \%$ SOC battery, which is also not in full charge, has an increase in the value of the output capacity during the discharging process, as shown in Figure 10.

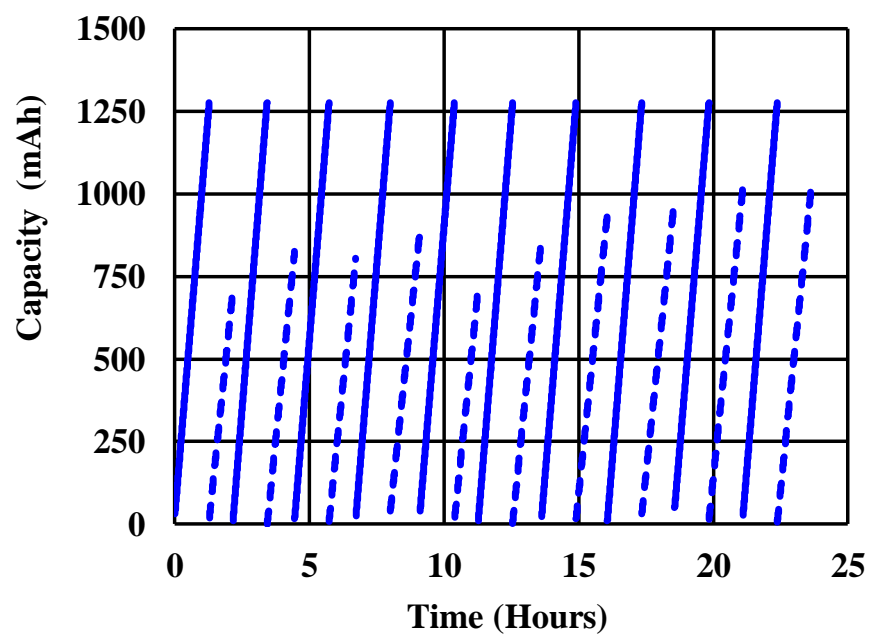

Figure 10. Ten cycles of $25 \%$ SOC capacity constant current charge $1 \mathrm{~A}$ and constant current discharge $0.8 \mathrm{~A}$.

The results of the SoC's discharge capacity of $25 \%$ are 10 cycles of $876 \mathrm{mAh}$. This result is relatively far from the calculation that has been determined by the SOC $25 \%$ to be $1275 \mathrm{mAh}$ ( $25 \%$ of 5100 $\mathrm{mAh})$. The three-cell dynamic battery that is 
made is proven a low performance when given a charge of $25 \%$ of the full charge state. In fact, the dynamic three-cell battery is not able to be applied by charging it briefly.

Figure 10 shows the SOC discharge capacity of $25 \%$ at cycles $1,3,5$ fluctuating. However, in the 6th to 10th cycles, the trend of the capacity value graph increased significantly. These results indicate that the treatment of SOC $25 \%$ discharging current of $0.8 \mathrm{~A}$ in the cycle range $1-5$ the battery capacity is not full. The results of 10 cycles of SOC $100 \%, 50 \%$, and $25 \%$ were analyzed by calculating the voltage efficiency, capacity efficiency, and energy efficiency as in the previous study ${ }^{27}$ to test battery performance from the $100 \%, 50 \%$, and $25 \%$ SOC treatment. Percentage of calculation analysis of voltage efficiency, capacity efficiency, and energy efficiency of 10 cycles shown in the form of a histogram in Figures $11,12,13$.

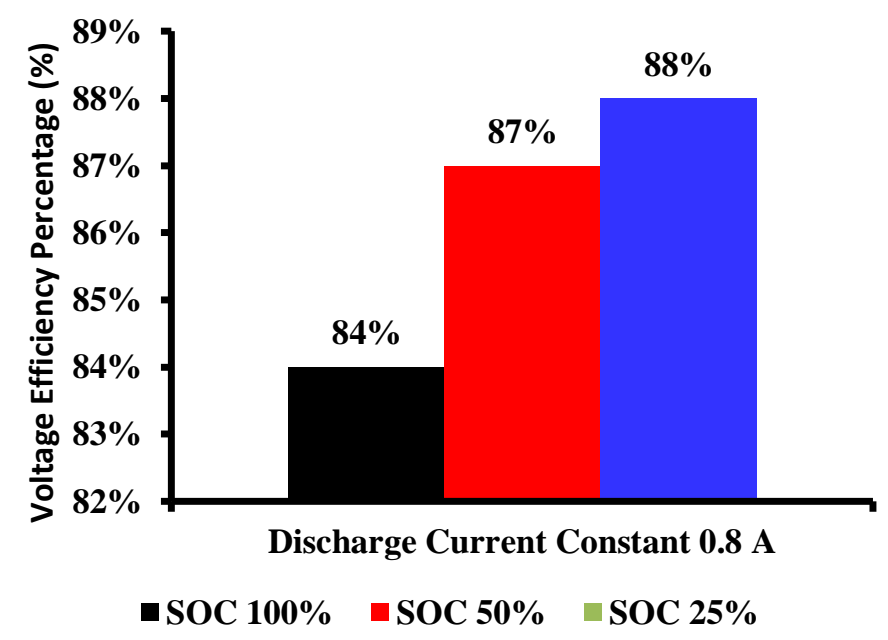

Figure 11. Voltage efficiency 0.8 A discharge current

Figure 11. The stress efficiency tends to experience a reverse ratio in value while increasing SOC treatment. When the SOC is
$100 \%$, the average discharge voltage is smaller than the average charging voltage value.

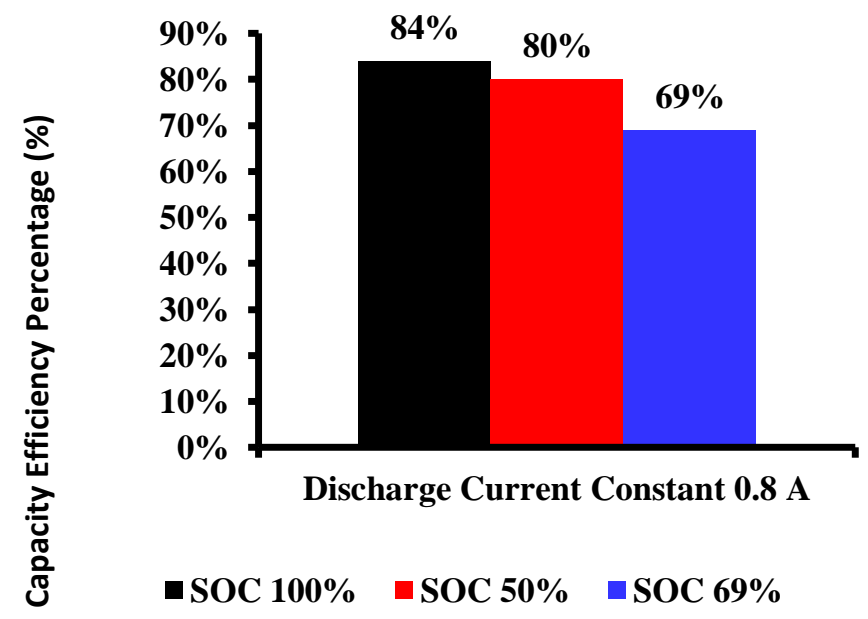

Figure 12. Discharge current capacity efficiency $0.8 \mathrm{~A}$.

Figure 12. Capacity efficiency has a value proportional to the greater SOC value. This is indicated the battery can store a larger charge, which means that the fully-charged battery has the maximum mutant storage performance. This result is also supported by his research ${ }^{23}$ which states that a battery with a full charge has a better average 
capacity efficiency value than a battery that is not in full charge or SOC $50 \%$ and SOC $25 \%$. This means that a battery with a longer charge has a greater capacity efficiency value. Capacity efficiency is predicted to decrease if more than 10 charge-discharge cycles are applied.

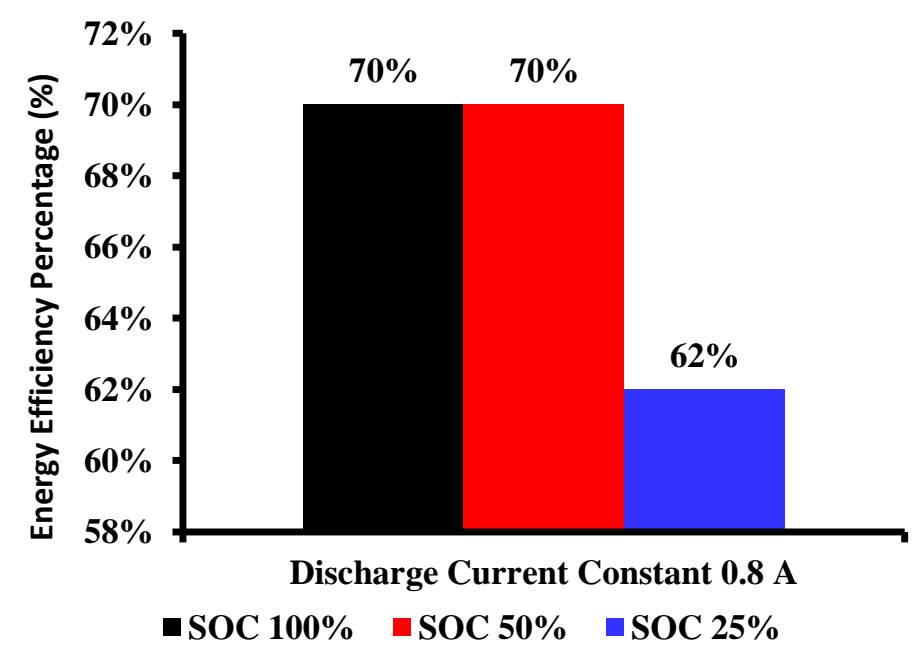

Figure 13. Energy efficiency 0.8 A discharge current

Figure 13.Energy efficiency at $100 \%$ and $50 \%$ SOC conditions has the same energy density performance, which means that it can be used as a recommendation that a battery that is designed even if the charging condition is carried out at $50 \%$ of the total battery capacity provides maximum electrical energy if used under usage conditions. . However, if the battery is carried out, the SOC condition is $25 \%$, which means that it is less than $50 \%$ the condition for charging the battery which is designed is still not optimal for regular use.

\section{Conclusion}

Treatment of SOC conditions for analyzing battery performance is tested at the analysis of the efficiency of voltage, capacity, and energy at full charge and half of the full charge state. It has been concluded as follows:

1. Estimated initial battery capacity of $5331 \mathrm{mAh}$ through the initial discharge test of the battery capacity with a constant current of $0.8 \mathrm{~A}$.

2. When pre-charging with a constant current of $1 \mathrm{~A}$ at SOC $1005,50 \%$, and $25 \%$, the battery is designed to have a charger cutoff voltage in the operating voltage range of 6.86-7.21 V.
3. When discharging with a constant current of $0.8 \mathrm{~A}$ at each SOC treatment of $100 \%, 50 \%$, and $25 \%$, the voltage drops at the same value, namely at the value of $5.41 \mathrm{~V}$. However, the length of the discharge range is longer at $100 \%$ SOC, then followed by SOC $50 \%$, then $25 \%$ which took about 5.6 hours, 2.3 hours and 0.9 hours, respectively.

4. In the cyclability test of 10 cycles of charging $1 \mathrm{~A}$ and discharge of $0.8 \mathrm{~A}$, the graph of the voltage function of the $100 \%$ SOC battery takes a long time of 149 hours, 50\% SOC requires 52 hours, $25 \%$ SOC requires 23.6 hours.

5. In the cyclability test of 10 charging cycles of $1 \mathrm{~A}$ and discharge of $0.8 \mathrm{~A}$, the battery capacity graph is the $100 \%$ SOC time function giving the train discharge capacity of $5100 \mathrm{mAh}$, SOC $50 \%$, with an average discharge capacity of $2048 \mathrm{mAh}$, and $25 \%$ of 876 mAh. The results of the $25 \%$ SoC test treatment showed a decrease in poor capacity performance and too far from the SoC $25 \%$ charging capacity target of $1275 \mathrm{mAh}$.

6. The energy efficiency of $100 \%$ and $50 \%$ SOC batteries provides the same 
good battery performance as indicated by the same $100 \%$ and $50 \%$ SOC energy efficiency values which can be used as a recommendation that a battery that is designed can be operated periodically even though the charging condition is $50 \%$ of the full charge.

\section{Acknowledgment}

The author thanks undergraduate students at the department of physics, the University of Brawijaya, who conduct the research. Also, thank Freygieon Ogiek Rizal Sukma for their contribution by providing the scientific data and references.

\section{References}

1. PLN. Keputusan Menteri Energi Sumber Daya Mineral Republik Indonesia No. 1567 K/21/MEM/2018. 2018.

2. Lubis, A. Energi Terbarukan Dalam Pembangunan Berkelanjutan. J. Badan Pengkaj. dan Penerapan Teknol. 2007; 8: 155-162.

3. Azhar M, Satriawan DA. Implementasi Kebijakan Energi Baru dan Energi Terbarukan Dalam Rangka Ketahanan Energi Nasional. Administrative Law and Governance Journal. 2018 Nov 30;1(4):398-412.

4. Skyllas-Kazacos M, Menictas C, Lim T. Redox flow batteries for medium-to large-scale energy storage. InElectricity Transmission, Distribution and Storage Systems 2013 1st January (pp. 398-441). Woodhead Publishing. doi:10.1533/9780857097378.3.398.

5. Alotto P, Guarnieri M, Moro F, Stella A. Redox Flow Batteries for large scale energy storage. In2012 IEEE International Energy Conference and Exhibition (ENERGYCON) 2012 9th September (pp. 293-298). IEEE. doi:10.1109/EnergyCon.2012.6347770

6. Minke C, Turek T. Materials, system designs and modelling approaches in techno-economic assessment of allvanadium redox flow batteries-A review. Journal of Power Sources. 2018
Feb 1;376:66-81.

7. Zhang J, Jiang G, Xu P, Kashkooli AG, Mousavi M, Yu A, Chen Z. An allaqueous redox flow battery with unprecedented energy density. Energy \& Environmental Science. 2018;11(8):2010-5.

8. Pan F, Wang Q. Redox species of redox flow batteries: a review. Molecules. 2015 Nov;20(11):20499-517.

9. Pranata KB, Sulistyanto MP, Amirullah AA, Yusmawanto M, Khairati N, Setiawan YE, Susilo RD, Perwita CA, Istiroyah I, Ghufron M. Static and Dynamic Characteristic Lead Acid Redox Flow Battery. InAIP Conference Proceedings 2021 (Vol. 50007, No. 2018).

10. Kosta S, Sneha R, Rana K. Design, Fabrication and Electrochemical performance of Soluble Lead RedoxFlow Battery for Energy Storage. In 2018 20th National Power Systems Conference (NPSC) 2018 14th December (pp. 1-6). IEEE. doi:10.1109/NPSC.2018.8771752.

11. Amit L, Naar D, Gloukhovski R, la O' GJ, Suss ME. A single-flow battery with multiphase flow. ChemSusChem. 2021 Feb 18;14(4):1068-73. doi:10.1002/cssc.202002135.

12. Cheng J, Zhang L, Yang YS, Wen YH, Cao GP, Wang XD. Preliminary study of single flow zinc-nickel battery. Electrochemistry Communications. 2007 Nov 1;9(11):2639-42.

13. Wang X, Chai J. Redox flow batteries based on insoluble redox-active materials. A review. Nano Materials Science. 2021 Mar 1;3(1):17-24. doi:10.1016/j.nanoms.2020.06.003.

14. Zhang, D., Liu, Q. \& Li, Y. Design of flow battery. React. Process Des. Sustain. Energy Technol. 61-97 (2014) doi:10.1016/B978-0-444-595669.00003-X.

15. Soloveichik GL. Flow batteries: current status and trends. Chemical reviews. 2015 Oct 28;115(20):11533-58.

16. Sánchez-Díez E, Ventosa E, Guarnieri 
M, Trovò A, Flox C, Marcilla R, Soavi F, Mazur P, Aranzabe E, Ferret R. Redox flow batteries: Status and perspective towards sustainable stationary energy storage. Journal of Power Sources. 2021 Jan;481:228804.

17. Collins J, Kear G, Li X, Low CJ, Pletcher D, Tangirala R, StrattonCampbell D, Walsh FC, Zhang C. A novel flow battery: A lead acid battery based on an electrolyte with soluble lead (II) Part VIII. The cycling of a $10 \mathrm{~cm} \times$ $10 \mathrm{~cm}$ flow cell. Journal of Power Sources. 2010 15th March;195(6):17318.

18. Bates A, Mukerjee S, Lee SC, Lee DH, Park S. An analytical study of a leadacid flow battery as an energy storage system. Journal of Power Sources. 2014 Mar 1;249:207-18.

19. Sadeghi S, Javaran EJ. Comparison of combining redox flow and lead-acid batteries with On-grid and stand-alone photovoltaic systems. Environmental Progress \& Sustainable Energy. 2019 Sep;38(5):13182.

20. Santos RM, Alves CL, Macedo EC, Villanueva JM, Hartmann LV, Catunda SY. Lead acid battery SoC estimation based on extended Kalman Filter method considering different temperature conditions. In2017 IEEE International Instrumentation and Measurement Technology Conference (I2MTC) 2017 22nd May (pp. 1-6). IEEE. doi:10.1109/I2MTC.2017.7969966.

21. Chitnis MS, Pandit SP, Shaikh MN. Electric Vehicle Li-Ion Battery State of Charge Estimation Using Artificial Neural Network. In2018 International Conference on Inventive Research in Computing Applications (ICIRCA) 2018 11th July (pp. 992-995). IEEE.

doi:10.1109/ICIRCA.2018.8597234.

22. Surendar V, Mohankumar V, Anand S, Prasanna VD. Estimation of state of charge of a lead acid battery using support vector regression. Procedia Technology. 2015 1st January;21:26470.
23. Ghufron M, Pranata KB, Istiroyah I, Yusmawanto M, Khairati N, Setiawan YE, Susilo RD, Amirullah AA, Perwita CA. Charging time influence on dynamic lead acid battery capacity with $\mathrm{H} 2 \mathrm{SO} 4$ electrolyte. InAIP Conference Proceedings 2018 17th October (Vol. 2021, No. 1, p. 050006). AIP Publishing LLC.

24. Ramadhan FR, Ghufron M, Khairati N, Setiawan YE, Pranata KB. Influence of discharge current on 3 cells dynamic lead-acid batteries performance. InIOP Conference Series: Materials Science and Engineering 2019 1st June (Vol. 546, No. 4, p. 042009). IOP Publishing.

25. Han J, Kim D, Sunwoo M. State-ofcharge estimation of lead-acid batteries using an adaptive extended Kalman filter. Journal of Power Sources. 2009 Mar 15;188(2):606-12.

26. Huang CS, Balagopal B, Chow MY. Estimating battery pack soc using a cellto-pack gain updating algorithm. InIECON 2018-44th Annual Conference of the IEEE Industrial Electronics Society 2018 21st October (pp. 18071812). IEEE.

27. Pranata KB, Sulistyanto MP, Ghufron M, Yusmawanto M. Pengaruh Variasi Arus Pengisian Pengosongan Muatan pada Model Baterai Lead Acid Terhadap Perubahan Efisiensi Energi. Jurnal Fisika Flux: Jurnal Ilmiah Fisika FMIPA Universitas Lambung Mangkurat. 2019;16(1):42-7. 